\title{
傾斜地ほ場における熱水土堙消毒による ホウレンソウ萎ちょう病防除
}

\author{
岩本 豊・高木 廣*・長田靖之・西村いつき** \\ （兵庫県立中央農業技術センター・*兵庫県立北部農業技術センター・**八鹿農業改良普及センター）
}

本県中山間地域の開発造成畑では，地理的条件を生か したホウレンソウの雨除け栽培が行われているが, 連作 により夏季の高温期を中心に萎ちょう病が発生し, 問題と なっている。当初，防除対策として太陽熱消毒が試みられ たが, 栽培地域か潐高冷地の畑地であるため，消毒のため の地温確保が困難であり，必ずしも十分な効果が得られな かった。また，近年，農薬の環境に対する影響か懸念され るなか, 消費者の農作物に対する安全性への関心が高まっ てきて㧍り，環境への負荷が少なく，安定した防除効果が 得られる土壤病害対策の確立が望まれている。

熱水土壤消毒法は，これまでにホウレンソウ萎ちょ う病 ${ }^{1}$, コムギ立枯病 ${ }^{5}$; 多イズ黑根腐病 ${ }^{4}$ 等の土畩病 害の他, キタネグサレセンチュウ, サッマイモネコブ センチュウ3)に対する防除効果が報告されている。本 報では中山間地域の傾斜地ほ場における本消毒法の木 ウレンソウ萎ちょう病に対する防除効果と現地適応性 について検討したので報告する。

\section{試 験 方 法}

試験は1998年 5 月に兵庫県養父群大屋町お扔や高原 の農家ほ場 (標高約 $700 \mathrm{~m}$, 砂壤土, 傾斜度 : 平坦地ほ場 $1.5 \%$ ，傾斜地ほ場 $6.7 \%$ ) で実施した。雨除けハウス内 の土壤を耕耘・整地後, 散水管を土䁃表面に敷設し, ビ ニールシートで全面被覆した。次に, 熱水土壤消毒機(丸 文製作所, $\mathrm{BW}-40)$ 上り散水管に送湯し, 土䁃中に熱 水を注入した(以下熱水処理とする)。排出湯温は $82^{\circ} \mathrm{C}$ 以

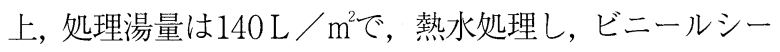
卜は処理後数日間被覆したまま放置した。ホウレンソウ の栽培は, 熱水処理後連続 2 作 ( 1 作目: 品種オリオン, 播種日一収穫日 1998 年 6 月 1 日 -7 月 2 日, 2 作目: 品 種アクティブ, 播種日一収穫日：7月 6 日 -8 月 4 日）
行った。播種は平畧, 直播きとし, 真空播種機を用いて 株間 $5.5 \mathrm{~cm}$, 条間 $18 \mathrm{~cm}$ で播種した。施肥, 一般管理は農 家慣行に従った。

生育調査は本葉 3〜 4 葉期に行い, それぞれの試験区 で任意に20株を選び, 葉数及び葉長 (最大葉)を測定した。 発病調査は収穫時に実施し, それぞれの試験区で10力所, 連続する50株を対象に萎调, 枯死株を調査し発病株率を 算出した。収量調查は, 各試験区で任意に 20 株を選び, 株重, 草丈, 葉数, 葉長を調査し, 単位面積あたり株重よ り収量を算出した。また, 熱水処理時及びその後の地温 変化は, 八ウス内 3 地点 (散水管両端部及び中央部) の地 表下 $10 \mathrm{~cm}$ 及び $20 \mathrm{~cm} て ゙$ 自記温度計を用いて測定した。土壤 中のFusarium属菌の菌密度は, 熱水処理前, 処理直後, ホウレンソウ収穫時にハウス内 5 地点から採取した土壤 （地表下 5 ～20cm) を混合し, 駒田培地を用いた希釈平板 法により求めた。

\section{結果及び考察}

熱水注入後の地温変動は, 平坦地ほ場では熱水注入開 始後速やかに上昇し，地表下 $20 \mathrm{~cm} に$ 打いても約 2 時間後 にはFusarium属菌に対して殺菌効果が認められる $55^{\circ} \mathrm{C}^{2}$ を越えた。また, 熱水注入停止後の地温効果は緩慢であ $\eta$, 地温 $55^{\circ} \mathrm{C}$ 以上持続時間は約 3 時間であった。傾斜地

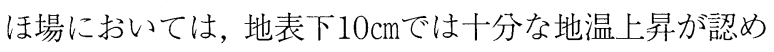

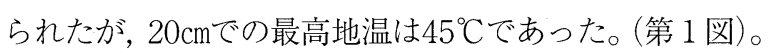

土㙵中のFusarium属菌数の変化を調査すると, 平坦 地ほ場無処理区の菌数がホウレンソウ作付けによって 急激に増加したのに対して, 熱水処理区は平坦地ほ場, 傾斜地ほ場ともに顕著に菌数は減少した。しかし, 傾 斜地ほ場においては, 熱水処理後のホウレンソウの連 作により菌密度の増加が確認された (第 1 表)。

Yutaka Iwamoto, Hiroshi Takaki*, Yasuyuki Osada and Itsuki Nishimura** (Hyogo Pref. Agric. Inst, *Hyogo Pref. Hokubu Agric. Inst, ${ }^{* *}$ Yoka Agric. Ext. Ctr.) : Effect of soil sterilization with hot water injection for control of Fusarium wilt of spinach in sloping field.

2000年 2 月24日受理 


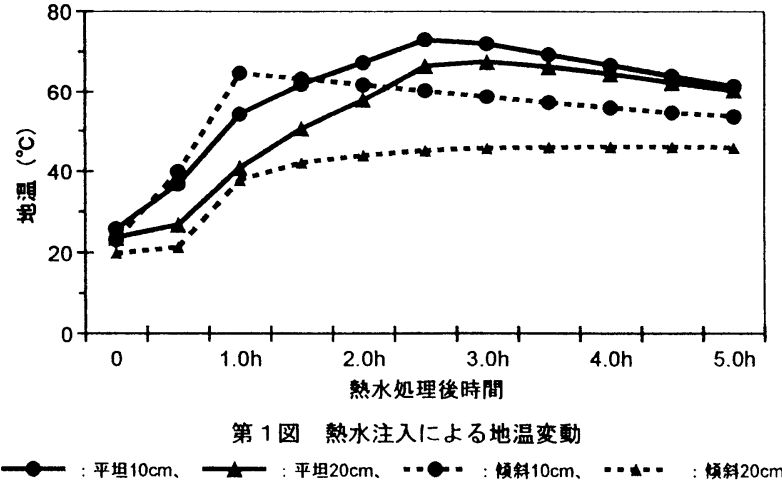

第 1 表 熱水消毒が土壤中のFusarium属菌数に及ぼす影響

\begin{tabular}{|c|c|c|c|c|c|}
\hline \multirow{2}{*}{ 供試ほ場 } & \multirow{2}{*}{ 熱水消毒 } & \multicolumn{4}{|c|}{ Fusarium属菌のコロニー数 $\left(10^{3} \mathrm{cfu} / \mathrm{g}\right)$} \\
\hline & & 処理前 & 処理後 & 1 作後 & 2 作後 \\
\hline \multirow[t]{2}{*}{ 平坦地ほ場 } & 処理区 & $2.5^{*}$ & $<0.1$ & $<0.1$ & 0.1 \\
\hline & 無処理区 & 7.3 & - & 190.0 & 290.0 \\
\hline 傾斜地ほ場 & 処理区 & 6.5 & $<0.1$ & 0.2 & 4.5 \\
\hline
\end{tabular}

数字は, ほ場内 5 地点の平均值

平坦地，傾斜地ほ場の熱水処理後 1 作目のホウレンソ ウ萎ちょう病の発生株率は，それぞれ $2.2 \%, 5.8 \%$ と 平坦地無処理区の $79.2 \%$ と比較して，非常に高い防除効 果が認められた。また，熱水処理後ホウレンソウを 2 連 作した場合は，平坦地ほ場処理区に比較して傾斜地ほ場 処理区の効果はやや劣ったが，両処理区とも防除効果が 認められ，効果の持続性が確認された (第 2 図)。

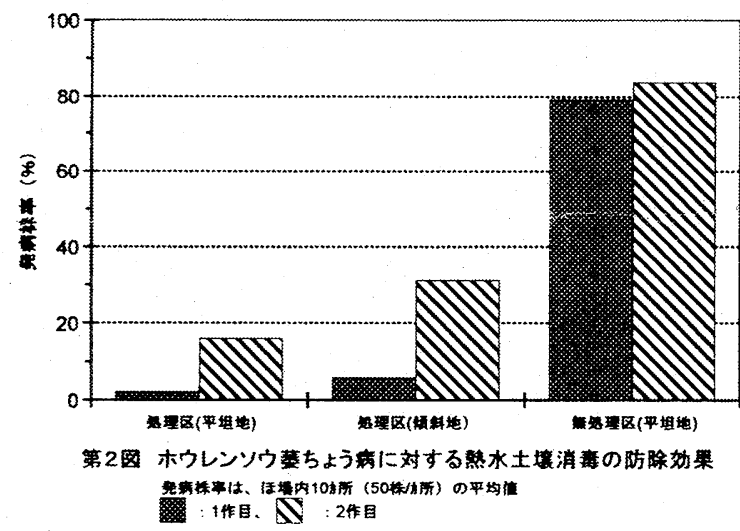

傾斜地ほ場の効果の持続性が平坦地ほ場と比べて劣っ た原因として，平坦地ほ場では注入した熱水は垂直方向 へ速やかに浸透し，水平方向にはあまり浸透しないとさ れている ${ }^{4)}$ 。一方，傾斜地ほ場では，処理時の熱水の流 れを観察すると，注入した熱水が地表面やビニールシー 卜を伝って地表を水平移動していたことから，熱水が土 壤中に十分に垂直浸透する前に地表面を流れ，土壌深部 の地温上昇が不十分となったためと考えられる。

熱水土壤消毒直後に播種したホウレンソウの発芽 率は無処理区とほぼ同程度であった。その後，無処 理区のホウレンソウが萎ちょう病による著しい生育 抑制を受けたのに対して，熱水処理区の生育は，平 担地ほ場，傾斜地ほ場とも生育障害等は認められず 良好であった。収穫時の調査では，生育，収量とも 熱水処理区が無処理区に著しく優った。(第 2 表)。

中山間地のホウレンソウ栽培地域では，ほ場傾斜が 10\%を越える急傾斜地での栽培も行われており, 今後, 急傾斜地ほ場における適応性の検討が必要であると考 えられる。しかし，本試験の結果から，熱水土塞消毒 は傾斜度 $6 \sim 7 \%$ 程度の緩傾斜地ほ場でも，平坦地ほ 場における防除効果と比較して効果の持続性でやや劣 るものの，実用上十分な防除効果が得られ，ホウレン ソウ萎ちょう病に対する土塞消毒法として適応可能で あると判断された。

\section{引用 文 献}

1 ) 國安克人 · 萩原廣 · 河本征臣 · 西和文 ·百田洋 二（1990） 日植病報 $56: 393$

2 ) 國安克人・西和文・百田洋二・竹下定男（1991） 植物防疫 $45: 247-251$

3 ) 百田洋二 ・西 和文・萩原 廣 - 國安克人 (199 1）日植病報 $57: 127$

4 ）西和文・國安克人 ·高橋廣治（1990）菌草研究 所研報 $28: 293-305$

5 ) 西 和文・佐藤 剛 - 福田徳治 (1992) 関東病虫 研報 $39: 39-42$

第 2 表 熱水消毒がホウレンソウの生育・収量に及ぼす影響

\begin{tabular}{|c|c|c|c|c|c|c|c|c|c|c|c|c|}
\hline \multirow{3}{*}{ 供試ほ場 } & \multirow{3}{*}{ 熱水消毒 } & \multirow{3}{*}{$\begin{array}{c}\text { 発芽率 } \\
(\%)\end{array}$} & \multicolumn{3}{|c|}{ 生育調査 } & \multicolumn{7}{|c|}{ 収量調査 } \\
\hline & & & \multirow[t]{2}{*}{ 葉 } & \multirow[t]{2}{*}{ 数 } & \multirow{2}{*}{$\begin{array}{c}\text { 葉 長 } \\
(\mathrm{cm})\end{array}$} & \multirow{2}{*}{$\begin{array}{l}\text { 株 重 } \\
(\mathrm{g})\end{array}$} & \multirow{2}{*}{$\begin{array}{c}\text { 草 丈 } \\
(\mathrm{cm})\end{array}$} & \multirow[t]{2}{*}{ 葉 } & \multirow[t]{2}{*}{ 数 } & \multicolumn{2}{|c|}{ 最大葉 $(\mathrm{cm})$} & \multirow{2}{*}{$\begin{array}{l}\text { 収 量 } \\
(\mathrm{kg} / \mathrm{a})\end{array}$} \\
\hline & & & & & & & & & & 葉 長 & 葉 幅 & \\
\hline \multirow{2}{*}{ 平坦地ほ場 } & 処理区 & 73.6 & & .7 & 10.2 & 26.5 & 23.8 & & 3.5 & 12.7 & 10.0 & 292 \\
\hline & 無処理区 & 68.7 & & 3 & 8.7 & 6.0 & 12.8 & & .6 & 6.9 & 4.9 & 64 \\
\hline 傾斜地ほ場 & 昜 処理区 & - & & .0 & 11.1 & 23.0 & 23.7 & & 3.5 & 12.7 & 9.0 & 226 \\
\hline
\end{tabular}

播種一収穫： $6 / 1-7 / 2$, 品種：オリオン, 調査株数: 発芽率 300 株, 生育調査・収量調査 20 株

調査月日 : 発芽調査1998年 6 月 8 日, 生育調査 6 月 22 日, 収量調査 7 月 2 日 